\title{
PERUBAHAN PARADIGMA PENDIDIKAN: PENINGKATAN LAYANAN PROFESIONAL MELALUI PEMBELAJARAN AUTENTIK DAN ASESMEN AUTENTIK
}

\author{
Prof. Dr.Festiyed, MS *) \\ Prodi Pendidikan Fisika PPS UNP Padang \\ Hp.08126742403 dan E-mail festiyed@ymail.com
}

\begin{abstract}
Abstrak
Pendidikan bertujuan mempersiapkan para individu siap hidup di dunia di mana masalah-masalah muncul jauh lebih cepat daripada jawaban masalah tersebut. Ketidakpastian dan ambiguitas dari perubahan dapat dihadapi secara terbuka, di mana setiap individu memiliki keterampilanketerampilan yang diperlukannya agar dapat hidup lebih nyaman dengan adanya perubahan daripada dengan adanya kepastian. Pembelajaran dan asesmen autentik adalah suatu cara untuk memfasilitasi peserta didik untuk berfikir kreatif, kritis, efektif dan inovatif. Melalui cara ini diharapkan lulusan mampu memberikan pelayanan yang profesional sebagai pendidik. Secara umum "Pelayanan Profesional Kegiatan Pembelajaran" dirancang melalui pembelajaran yang autentik dan dan asesmen yang autentik pula, untuk memberikan arahan pada guru pada saat melaksanakan proses pembelajaran di depan kelas. Guru diharapkan dapat menyediakan pengalaman belajar dan asesmen yang beragam baik mental, fisik dan sosial, sehingga pengetahuan, sikap dan ketrampilan berkembang seimbang.
\end{abstract}

\section{PENDAHULUAN}

Kemajuan teknologi komunikasi dan informasi yang berkembang begitu pesat pada era globalisasi, membawa perubahan yang sangat radikal. Perubahan itu telah berdampak pada setiap aspek kehidupan, termasuk pada system pendidikan dan pembelajaran di PPS Universitas Negeri Padang. Dampak dari perubahan yang luar biasa itu terbentuknya suatu 'kumonitas global', lebih parah lagi karena komunitas

\footnotetext{
${ }^{*}$ Dosen Prodi Pendidikan Fisika PPS Universitas Negeri Padang, Disampaikan Pada Seminar Nasional dan Forum Pimpinan Pascasarjana LPTK Negeri se Indonesia. Dengan Tema: Mewujudkan sinergisitas LPTK dalam mengembangkan kemitraan sumber daya Pascasarjana LPTK di era MEA, 7-9 oktober 2016 di Training Centre, Damhill Hotel, Universitas Negeri Gorontalo
} 
global itu ternyata tiba jauh lebih cepat dari yang diperhitungkan: revolusi informasi telah menghadirkan dunia baru yang benar-benar hyper-reality.

Paradigma baru dalam pendidikan masa depan mengisyaratkan aktualisasi keunggulan kemampuan manusia. Untuk mengaktualisasikannya ada dua pendekatan yang dapat dilakukan yaitu: Pengembangan sumber daya manusia dan pengembangan kemampuan manusia yang saling melengkapi,

1. Pengembangan sumber daya manusia atau Human Resource Development $(H R D)$, terutama terfokus pada keterampilan, sikap dan kemampuan produktif ketenagakerjaan sehingga diperlakukan manusia sebagai "sumber untuk dimanfaatkan" (yaitu sebagai obyek), dalam mencapai tujuan ekonomi, terutama dalam jangka waktu pendek. Pengembangan itu tidak terjadi dari dalam, melainkan "diatur dari atas" sesuai kepentingan lingkungannya.

2. Pengembangan kemampuan manusia atau Human Capacity Development $(H C D)$ sepanjang hayat yang berhak dan mampu memilih berbagai peran dalam meraih berbagai peluang partisipasi, sebagai anggota masyarakat, sebagai orang tua, atau sebagai pekerja dan konsumen, yaitu suatu perkembangan yang arah dan sasarannya terutama terjadi dari dalam, namun disulut untuk aktualisasinya. Karena itu, HCD menunjuk pada konstelasi keterampilan, sikap dan perilaku dalam melangsungkan hidup mencapai kemandirian (Levinger,1996), sekaligus memiliki daya saing tinggi dan daya tahan terhadap gejolak ekonomi dunia. HCD bermutu adalah proses kontekstual melalui upaya pendidikan bukanlah sebatas menyiapkan manusia menguasai pengetahuan dan keterampilan yang cocok dengan tuntutan dunia kerja pada saat ini, melainkan manusia yang mampu, mau, dan siap belajar sepanjang hayat, serta dilandasi sikap, nilai,etik dan moral. HCD tidak hanya terletak pada kecerdasan intelektual, tetapi kecerdasan emosional, kecerdasan sosial, kecerdasan moral, dan kecerdasan spiritual.

Manusia tidak bisa lagi hanya bergantung pada seperangkat nilai, keyakinan, dan pola aktivitas social yang konstan. Manusia dipaksa secara berkelanjutan untuk menilai kembali posisi sehubungan dengan faktor-faktor tersebut dalam rangka membangun sebuah konstruksi social-personal yang memungkin atau yang tampaknya memungkinkan. Jika masyarakat mampu bertahan dalam menghadapi tantangan perubahan di dalam dunia pengetahuan, teknologi, komunikasi serta konstruksi social budaya ini, maka kita harus mengembangkan proses-proses baru 
untuk menghadapi masalah-masalah baru ini. Kita tidak dapat lagi bergantung pada jawaban-jawaban masa lalu karena jawaban-jawaban tersebut begitu cepatnya tidak berlaku seiring dengan perubahan yang terjadi. Pengetahuan, metode-metode, dan keterampilan-keterampilan menjadi suatu hal yang ketinggalan zaman hampir bersamaan dengan saat hal-hal ini memberikan hasilnya.

Degeng (1998) menyatakan bahwa kita telah memasuki era kesemrawutan. Era yang datangnya begitu tiba-tiba dan tak seorang pun mampu menolaknya. Kita harus masuk di dalamnya. Pada era kesemrawutan ini tidak dapat dijawab dengan paradigma keteraturan, kepastian, dan ketertiban. Era kesemrawutan harus dijawab dengan paradigma kesemrawutan. Era kesemrawutan ini dilandasi oleh teori dan konsep konstruktivistik; suatu teori pembelajaran yang kini banyak dianut di kalangan pendidikan di AS. Unsur terpenting dalam konstruktivistik adalah kebebasan dan keberagaman. Kebebasan yang dimaksud ialah kebebasan untuk melakukan pilihanpilihan sesuai dengan apa yang mampu dan mau dilakukan oleh si belajar. Keberagaman yang dimaksud adalah si belajar menyadari bahwa individunya berbeda dengan orang/kelompok lain, dan orang/kelompok lain berbeda dengan individunya.

Alternatif pendekatan pembelajaran ini bagi Indonesia yang sedang menempatkan reformasi sebagai wacana kehidupan berbangsa dan bernegara, bukan hanya di bidang pendidikan, melainkan juga di segala bidang. Selama ini, wacana kita adalah behavioristik yang berorientasi pada penyeragaman yang pada akhirnya membentuk manusia Indonesia yang sangat sulit menghargai perbedaan. Perilaku yang berbeda lebih dilihat sebagai kesalahan yang harus dihukum. Perilaku manusia Indonesia selama ini sudah terjangkit virus kesamaan, virus keteraturan, dan lebih jauh virus inilah yang mengendalikan perilaku kita dalam berbangsa dan bernegara.

Longworth (1999) meringkas fenomenan ini dengan menyatakan: 'Kita perlu mengubah focus kita dan apa yang perlu dipelajari menjadi bagaimana caranya untuk mempelajari. Perubahan yang harus terjadi adalah perubahan dari isi menjadi proses. Belajar bagaimana cara belajar untuk mempelajari sesuatu menjadi suatu hal yang lebih penting daripada fakta-fakta dan konsep-konsep yang dipelajari itu sendiri'. 
Oleh karena itu, pendidikan harus mempersiapkan para individu untuk siap hidup dalam sebuah dunia di mana masalah-masalah muncul jauh lebih cepat daripada jawaban dari masalah tersebut, di mana ketidakpastian dan ambiguitas dari perubahan dapat dihadapi secara terbuka, di mana para individu memiliki keterampilan-keterampilan yang diperlukannya untuk secara berkelanjutan menyesuaikan hubungan mereka dengan sebuah dunia yang terus berubah, dan di mana tiap-tiap dan kita menjadi pemberi arti dari keberadaan kita. Beare \& Slaughter (1993) menagaskan, 'Hal ini tidak hanya berarti teknik-teknik baru dalam pendidikan, tetapi juga tujuan baru. Tujuan pendidikan haruslah untuk mengembangkan suatu masyarakat di mana orang-orang dapat hidup secara lebih nyaman dengan adanya perubahan daripada dengan adanya kepastian. Dalam dunia yang akan datang, kemampuan untuk menghadapi hal-hal baru secara tepat lebih penting daripada kemampuan untuk mengetahui dan mengulangi hal-hal lama. Untuk ini diperlukan cara berfikir kreatif, kritis, efektif dan inovatif.

Keadaan aktif dan menyenangkan tidaklah cukup jika proses pembelajaran tidak efektif, yaitu tidak menghasilkan apa yang harus dikuasai siswa setelah proses pembelajaran berlangsung, sebab pembelajaran memiliki sejumlah tujuan pembelajaran yang harus dicapai. Jika pembelajaran hanya aktif dan menyenangkan tetapi tidak efektif, maka pembelajaran tersebut tak ubahnya seperti bermain biasa.

Sedangkan inovatif suka merekonstruksi masalah, dan kemampuan menggunakan gagasan-gagasan atau ide-ide yang dilandasi oleh fakta dan informasi yang akurat dalam memecahkan atau mengatasi suatu masalah, dengan demikian kreativitas dalam pengertian kemampuan hanya mencakup dimensi kognitif. Ciri-ciri kreativitas tersebut belum sepenuhnya menjadi tolok ukur seseorang dapat disebut kreatif. Ciri lain yang harus dikembangkan yaitu ciri afektif menyangkut sikap dan perasaan seseorang, antara lain motivasi untuk berbuat sesuatu.

Berfikir kreatif dapat di defenisikan kedalam empat dimensi: berfokus pada pribadi, proses, dorongan dan produk. Kreatif berfokus pada pribadi muncul dari keunikan keseluruhan kepribadian dalam interaksi dengan lingkungannya. Kreatif yang berfokus pada dimensi proses mencerminkankelancaran, keluwesan, dan orisinal dalamberfikir, serta kemampuan untuk mengelaborasi (mengembangkan, 
memperkaya, memperinci) suatu gagasan. Kreatif dalam dimensi dorongan internal diri sendiri berupa keinginan dan hasrat untuk mencipta atau bersibuk diri secara kreatif, maupun eksternal dari lingkungan sosial dan psikologis. Kreatif dalam dimensi produk berfokus pada apa yang dihasilkan oleh individu baik sesuatu yang baru/original atau sebuah elaborasi/penggabungan yang inovatif (berbeda /lebih baik).

Berfikir Kritis mencakup ketrampilan menafsirkan dan menilai pengamatan, informasi, argumentasi, penggunaan alasan yang logis, mencakup ketrampilan membandingkan, meklasifikasikan, melakukan pengurutan, menghubungkan sebab akibat , mendeskripsikan pola, membuat analogi, menyusun rangkaian, memberialasan secara deduktif dan induktif, peramalan, perencanaan, perumusan hipótesis, dan penyampaian kritik. Dan berfikir inovatif mengembangkandan mengimplementasikan gagasan-gagasan baru oleh orang dimana dalam jangka waktu tertentu melakukan transaksi-transaksi dengan orang lain dalam suatu tatanan organisasi.

Kebutuhan akan orientasi baru dalam pendidikan ini terasa begitu kuat dan nyata dalam berbagai bidang studi, baik dalam bidang studi eksakta maupun ilmu-ilmu lainnya. Para pendidik, praktisi pendidikan dan kita semua, mau tidak mau harus merespon perubahan yang terjadi dengan mengubah paradigma pendidikan. Untuk menjawab dan mengatasi perubahan yang terjadi secara terus-menerus, alternatif yang dapat digunakan adalah layanan profesional untuk menciptakan suasana pembelajaran aktif, inovatif, kreatif, efektif dan menyenengkan melalui pendekatan saintifik agar dapat menstimulus banyak kecerdasan (Multiple Intelligences) yang dimiliki peserta didik.

\section{PERGESERAN PARADIGMA PENDIDIKAN}

Paradigma diartikan sebagai cara pandang seseorang terhadap diri dan lingkungannya yang akan memengaruhinya dalam berpikir (kognitif), bersikap (afektif), dan bertingkah laku (konatif). Paradigma juga dapat berarti seperangkat asumsi, konsep, nilai, dan praktek yang diterapkan dalam memandang realitas kepada sebuah komunitas yang sama, khususnya, dalam disiplin intelektual. Sehingga paradigma pendidikan adalah suatu cara memandang dan memahami pendidikan, dan dari sudut pandang ini kita mengamati dan memahami masalah- 
masalah pendidikan yang dihadapi dan mencari cara mengatasi permasalahan tersebut.

Di era globalisasi semua yang ada cepat berubah, maka dunia pendidikan juga harus berubah, sehingga dunia pendidikan menjadi relevan dengan tantangan dan peluang yang terjadi di kehidupan nyata. Dalam dunia kerja saat ini kemampuan yang diminta adalah kemampuan untuk bekerja sama dalam team, kemampuan pemecahan masalah, kemampuan untuk mengarahkan diri, berpikir kritis, menguasai teknologi serta mampu berkomunikasi dengan efektif. Kemampuan-kemampuan tersebut diatas disebut sebagai kemampuan abad ke-21, dan harus mampu dikembangkan secara sistematis dalam dunia pendidikan, proses pembelajaran harus mampu mendorong terciptanya kemampuan tersebut. Jadi selain kemampuan akademis maka dunia pendidikan harus mampu menciptakan manusia yang mempunyai kemampuan belajar, beradaptasi dan berinovasi.

Pergeseran paradigma pendidikan mencakup beberapa hal pokok yaitu :

1. Kebijakan pendidikan, kebijakan pendidikan harus menunjukkan arahan yang jelas mengenai tujuan dan target yang ingin dicapai serta cara untuk mencapainya. Kebijakan harus tetap fleksibel dan bisa diterapkan sesuai kondisi lokal. Kurikulum sebagai acuan dalam pengembangan pembelajaran dan sistem penilaian harus sudah mengarah pada pola pemblajaran abad 21 yang lebih berpusat pada siswa.

2. Pengembangan kompetensi Guru, guru sebagai motor terdepan dalam perubahan harus menjadi pihak pertama yang siap dalam proses perubahan ini. Guru harus mampu mengubah proses pembelajarannya dari yang tradisional berpusat pada guru menjadi berpusat pada siswa

3. Teknologi, integrasi teknologi dalam proses belajar merupakan sebuah keniscayaan, siswa harus diarahkan dan diberikan kesempatan yang sebesarbesarnya dalam mencari informasi sesuai dengan target pembelajaran. Pembelajaran dengan teknologi sebetulnya sama dengan proses bekerja dalam kehidupan nyata yang selalu bersinggungan dengan teknologi, yang artinya proses pembelajaran menjadi relevan dengan proses kerja.

4. Riset dan evaluasi, setiap proses apapun membutuhkan umpan balik untuk menyempurnakan sistemnya, oleh karena itu evaluasi menjadi penting untuk 
melihat dampak keberhasilan dari setiap kebijakan. Riset menjadi penting agar kita selalu dalam kondisi aktual dalam pengembangan dunia pendidikan.

Pergeseran paradigma pendidikan terjadi diberbagai tingkatan baik dari satuan terkecil di satuan pendidikan yaitu sekolah, perguruan tinggi maupun di tingkat pemerintahan dari tingkat kabupaten sampai nasional.

\section{Landasan Yurudis Pentingnya Merenovasi Proses Pembelajaran}

Seiring dengan berkembangnya cara berfikir dan teori pembelajaran modern, muncul pemikiran kritis untuk merenovasi proses pembelajaran yang berkualitas, humanis, dinamis dan konstruktif sebagai upaya untuk meningkatkan mutu pendidikan nasional. Upaya tersebut secara yuridis ditegaskan melalui beberapa kebijakan dan peraturan antara lain: Dalam Pasal 35 ayat 2 UndangUndang Nomor 12 Tahun 2012 tentang Pendidikan Tinggi dinyatakan bahwa Kurikulum Pendidikan Tinggi dikembangkan oleh setiap Perguruan Tinggi dengan mengacu pada Standar Nasional Pendidikan Tinggi untuk setiap Program Studi. Pengembangan kurikulum mencakup pengembangan kecerdasan intelektual, akhlak mulia, dan keterampilan lulusan perguruan tinggi. Pengembangan kurikulum juga harus mengacu kepada Kerangka Kualifikasi Nasional Indonesia (KKNI) sebagaimana diatur dalam Peraturan Presiden Nomor 8 tahun 2012 yang merupakan pernyataan kualitas sumber daya manusia Indonesia yang penjenjangan kualifikasinya didasarkan pada tingkat kemampuan yang dinyatakan dalam rumusan capaian pembelajaran (learning outcomes). Khusus LPTK yang memiliki program studi (prodi) kependidikan, pengembangan kurikulum juga mengacu kepada ketercapaian standar kompetensi profesi guru. Perguruan tinggi sebagai penghasil sumber daya manusia terdidik perlu mengukur lulusannya, apakah lulusan yang dihasilkan memiliki 'kemampuan' setara dengan 'kemampuan' (capaian pembelajaran) yang telah dirumuskan dalam jenjang kualifikasi KKNI dan standar kompetensi guru yang ditetapkan.

Guru merupakan jabatan professional yang memberikan layanan ahli dan menuntut persyaratan kemampuan yang secara akademik dan pedagogis maupun secara professional dapat diterima oleh semua pemangku kepentingan yang terkait, baik penerima jasa layanan secara langsung maupun pihak pembina guru dalam hal ini pemerintah pusat dan daerah. Guru sebagai penyandang jabatan 
professional harus disiapkan melalui program pendidikan yang relative panjang dan dirancang berdasarkan standar kompetensi guru. Oleh sebab itu diperlukan waktu dan keahlian untuk membekali para lulusannya dengan berbagai kompetensi yaitu penguasaan bidang studi, landasan keilmuan dari kegiatan mendidik, maupun strategi menerapkannya secara professional di lapangan.

Untuk mewujudkan profil lulusan guru yang professional, LPTK perlu merancang kurikulum yang menjamin ketercapaian kompetensi lulusan sesuai Standar Nasional Pendidikan Tinggi (SN Dikti). Pengembangan kurikulum di LPTK antara lain pengembangan serta penyusunan rencana dan pengaturan mengenai capaian pembelajaran, bahan kajian, proses dan penilaian yang diganakan sebagai pedoman penyelenggaraan pendidikan di Perguruan tinggi LPTK. Disamping kurikulum, perguruan tinggi diwajibkan menerapkan berbagai standar yang terdapat dalam Undang-Undang Nomor 20 Tahun 2003 Tentang Sistem Pendidikan Nasional dan peraturan lainnya yang terkait dengan terlaksananya penjaminan mutu internal dan eksternal.

\section{Pentingnya Layanan Profesional}

Layanan professional merupakan suatu kegiatan atau urutan kegiatan yang terjadi dalam interaksi langsung antara seseorang dengan orang lain secara professional sehingga dapat memuaskan pihak yang dilayani. Dengan layanan ini diharapkan kegiatan pembelajaran dapat dapat berjalan dengan baik, sehingga proses pembelajaran menjadi kegiatan yang menyenangkan peserta didik. Hal ini disebabkan karena layanan yang diberikan mampu memenuhii keinginan atau kebutuhan peserta didik.

Secara umum "Pelayanan Profesional Kegiatan Pembelajaran" dirancang untuk memberikan arahan pada guru pada saat melaksanakan proses pembelajaran di depan kelas. Guru diharapkan dapat menyediakan pengalaman belajar yang beragam baik mental, fisik dan sosial. Guru juga mengelola tempat belajar, siswa, kegiatan pembelajaran, isi/materi, sumber belajar sedemikian rupa sehingga siswa aktif bertanya, mempertanyakan, dan mengemukakan gagasan. Belajar memang merupakan suatu proses aktif dari si pembelajar dalam membangun pengetahuannya, bukan proses pasif yang hanya menerima kucuran ceramah guru tentang pengetahuan. Sehingga, jika pembelajaran tidak memberikan 
kesempatan kepada siswa untuk berperan aktif, maka pembelajaran tersebut bertentangan dengan hakikat belajar. Peran aktif dari siswa sangat penting dalam rangka pembentukan generasi yang kreatif, yang mampu menghasilkan sesuatu untuk kepentingan dirinya dan orang lain. Kreatif juga dimaksudkan agar guru menciptakan kegiatan belajar yang beragam sehingga memenuhi berbagai tingkat kemampuan siswa. Menyenangkan adalah suasana belajar-mengajar yang menyenangkan sehingga siswa memusatkan perhatiannya secara penuh pada belajar sehingga waktu curah perhatiannya tinggi. Menurut hasil penelitian, tingginya waktu curah terbukti meningkatkan hasil belajar (Festiyed, 2008).

Layanan profesional untuk menciptakan suasana pembelajaran aktif, inovatif, kreatif dan menyenangkan apabila siswa terlibat dalam berbagai kegiatan yang mengembangkan pemahaman dan kemampuan mereka dengan penekanan pada belajar melalui berbuat. Pembelajaran akan menyenangkan jika pembelajaran memberikan perlakuan bervariasi sesuai dengan gaya dan kecerdasan yang dimiliki peserta didik, karena setiap peserta didik memiliki kecerdasan dan kemampuan berbeda dalam memahami sebuah mata pelajaran, sehingga berbeda pula pengalaman yang diperolehnya (Festiyed, 2008). Pentingnya perlakuan guru yang bervariasi dalam pembelajaran, diperkuat oleh pendapat Edgare Dale yang mengemukakan teori kerucut pengalaman, dalam teori ini keberhasilan belajar diukur dengan kadar pengalaman belajar yang diperoleh peserta didik tergantung perlakukannya dalam belajar, baik perlakukan guru atau aktivitas peserta didik ketika belajar. Kerucut pengalaman tersebut seperti gambar berikut:

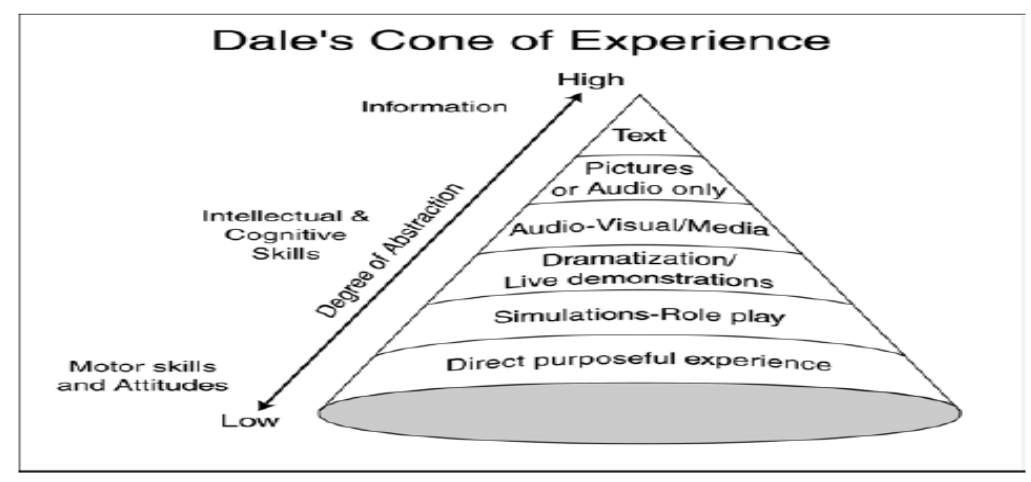

Gambar 1. Kerucut Pengalaman Edgare Dale 
Gambar 1, memperlihatkan rentangan tingkat pengalaman dari yang bersifat langsung hingga ke pengalaman melalui simbol-simbol komunikasi, yang merentang dari yang bersifat kongkrit ke abstrak, dan tentunya memberikan implikasi tertentu terhadap pemilihan metode dan bahan pembelajaran. Dalam arti belajar bukan hanya membaca atau mendengar saja tapi lebih dari itu belajar merupakan satu kesatuan yang terintegrasi sehingga tercipta suatu proses belajar yang maksimal. Seseorang dapat memprogram dirinya dalam konteks belajar tersebut untuk dapat mengerti suatu ilmu baru dengan metode-metode khusus yang dimilikinya. Inilah yang membedakan kualitas belajar seorang yang satu dengan proses belajar orang lain.

Seorang pendidik tidak boleh memaksakan peserta didiknya untuk memahami setiap pelajaran dengan pemahaman yang sama dan sempurna dengan satu takaran kecerdasan, sebab kecerdasan peserta didik dalam satu kelas berbeda-beda. Seorang pendidik harus mengakui dan menghargai bakat dan perbedaan kecerdasan peserta didiknya. Begitu juga pola pemikiran tradisional yang menekankan pada kemampuan logika dan bahasa dalam proses pembelajaran di kelas sudah waktunya diubah dengan kecerdasan majemuk yang pada dasarnya adalah sinergi dari kecerdasan otak (IQ), kecerdasan emosional (EQ) dan kecerdasan spiritual (SQ). Menurut Garnerd (1983;1993) Intellegence (Kecerdasan) adalah kemampuan untuk memecahkan persoalan dan menghasilkan produk dalam suatu setting yang bermacam-macam dan dalam situasi nyata

Peserta didik yang mempunyai taraf kecerdasan rendah atau di bawah normal sukar diharapkan berprestasi tinggi. Tetapi tidak ada jaminan bahwa dengan taraf kecerdasan tinggi seseorang secara otomatis akan sukses belajar di sekolah. Kecerdasan intelektual tidak hanya mencakup dua parameter tersebut, tetapi harus dilihat dari aspek kinetis, musical, visual-spatial,interpersonal, intrapersonal, dan naturalis (Kompas, 6 Agustus 2003: T.Amstrong, 2004). Jenis-jenis kecerdasan intelektual tersebut dikenal dengan sebutan kecerdasan jamak (Multiple Intelligences) yang diperkenalkan oleh Howard Gardner pada tahun 1983.

Gardner mengatakan bahwa kita cenderung hanya menghargai orang-orang yang memang ahli di dalam kemampuan logika (matematika) dan bahasa. Kita harus memberikan perhatian yang seimbang terhadap orang-orang yang memiliki talenta (gift) di dalam kecerdasan yang lainnya seperti artis, arsitek, musikus, ahli alam, 
designer, penari, terapis, entrepreneurs, dan lain-lain. Sangat disayangkan bahwa saat ini banyak peserta didik yang memiliki talenta (gift), tidak mendapatkan reinforcement di sekolahnya. Banyak sekali peserta didik yang pada kenyataannya dianggap sebagai peserta didik yang "Learning Disabled" atau ADD (Attention Deficit Disorder), atau Underachiever, pada saat pola pemikiran mereka yang unik tidak dapat diakomodasi oleh sekolah. Pihak sekolah hanya menekankan pada kemampuan logika (matematika) dan bahasa.

Teori ini membantu kita lebih memahami mengapa gaya belajar pada masingmasing orang berbeda. Dan, kita pun bisa membayangkan kenapa respon terhadap suatu hal tidak ada yang serupa antara satu orang dengan orang yang lain. Jadi ada spektrum yang sangat luas dari sisi metode, media, strategi, dan lingkungan belajar yang dapat dikembangkan bagi siapa pun, karena semua peserta didik itu cerdas dan ada banyak cara untuk mengembangkan keunikan talentanya. Sebagai contoh, apakah Einstein akan sukses seperti itu bila dia masuk di Jurusan Biologi atau belajar main bola dan Musik jelas masalah fisika-teoritis Einstein, Max Planc, Stephen Howking, Newton adalah jenius-jenius, tetapi bab olah-raga maka Zidane, Jordane, Maradona adalah jenius-jenius dilapangan, juga Mozart, Bach adalah jenius-jenius dimusik. Thomas A. Edison adalah jenius lain, demikian juga dengan para sutradara film, bagaimana mereka mampu membayangkan harus disyuting bagian ini, kemudian setelah itu, adegan ini, ini yang mesti keluar dengan pakaian jenis ini, latar suara ini, dan bahkan dialog seperti itu, ini adalah jenius-jenius bentuk lain. Disinilah Howard Gardner mengeluarkan teori baru dalam buku Frame of Mind, tentang Multiple Intelligences (Kecerdasan Majemuk), dimana dia mengatakan bahwa era baru sudah merubah dari Test IQ yang melulu hanya test tulis (dimana didominasi oleh kemampuan Matematika dan Bahasa), menjadi Multiple Intelligences. Ada delapan macam Multiple Intelligences.yang diungkapkan oleh Gardner (1983) yaitu:Teori Multiple Intelligences didasarkan pada pemikiran bahwa kemampuan intelektual yang diukur melalui tes IQ sangatlah terbatas karena tes IQ hanya menekan pada kemampuan logika (matematika) dan bahasa (Gardner, 2003). Padahal setiap orang mempunyai cara yang unik untuk menyelesaikan persoalan yang dihadapinya. Kecerdasan bukan hanya dilihat dari nilai yang diperoleh seseorang. Kecerdasan merupakan kemampuan yang dimiliki oleh 
seseorang untuk melihat suatu masalah, lalu menyelesaikan masalah tersebut atau membuat sesuatu yang dapat berguna bagi orang lain.

\section{PEMBELAJARAN AUTENTIK DAN ASESMEN AUTENTIK}

Asesmen autentik mengharuskan pembelajaran yang autentik pula. Pembelajaran autentik adalah suatu cara untuk memfasilitasi peserta didik dalam pembelajaran yang kolaboratif, kooperatif, kompetitif dan karakter, yang diharapkan dapat memberikan layanan yang proesional sebagai pendidik. Menurut Ormiston belajar autentik mencerminkan tugas dan pemecahan masalah yang diperlukan dalam kenyataannya di luar sekolah. Asesmen Autentik terdiri dari berbagai teknik:

1. Pengukuran langsung keterampilan peserta didik yang berhubungan dengan hasil jangka panjang pendidikan seperti kesuksesan di tempat kerja.

2. Penilaian atas tugas-tugas yang memerlukan keterlibatan yang luas dan kinerja yang kompleks.

3. Analisis proses yang digunakan untuk menghasilkan respon peserta didik atas perolehan sikap, keteampilan, dan pengetahuan yang ada.

Dengan demikian, asesmen autentik akan bermakna bagi guru untuk menentukan cara-cara terbaik agar semua siswa dapat mencapai hasil akhir, meski dengan satuan waktu yang berbeda. Konstruksi sikap, keterampilan, dan pengetahuan dicapai melalui penyelesaian tugas di mana peserta didik telah memainkan peran aktif dan kreatif. Keterlibatan peserta didik dalam melaksanakan tugas sangat bermakna bagi perkembangan pribadi mereka.

Dalam pembelajaran autentik, peserta didik diminta mengumpulkan informasi dengan pendekatan saintifik, memahahi aneka fenomena atau gejala dan hubungannya satu sama lain secara mendalam, serta mengaitkan apa yang dipelajari dengan dunia nyata yang luar sekolah. Di sini, guru dan peserta didik memiliki tanggung jawab atas apa yang terjadi. Peserta didik pun tahu apa yang mereka ingin pelajari, memiliki parameter waktu yang fleksibel, dan bertanggungjawab untuk tetap pada tugas. Asesmen autentik pun mendorong peserta didik mengkonstruksi, mengorganisasikan, menganalisis, mensintesis, menafsirkan, menjelaskan, dan mengevaluasi informasi untuk kemudian mengubahnya menjadi pengetahuan baru.

Sejalan dengan deskripsi di atas, pada pembelajaran autentik, guru harus menjadi "guru autentik." Peran guru bukan hanya pada proses pembelajaran, melainkan juga 
pada penilaian. Untuk bisa melaksanakan pembelajaran autentik, guru harus memenuhi kriteria tertentu seperti disajikan berikut ini.

1. Mengetahui bagaimana menilai kekuatan dan kelemahan peserta didik serta desain pembelajaran.

2. Mengetahui bagaimana cara membimbing peserta didik untuk mengembangkan pengetahuan mereka sebelumnya dengan cara mengajukan pertanyaan dan menyediakan sumberdaya memadai bagi peserta didik untuk melakukan akuisisi pengetahuan.

3. Menjadi pengasuh proses pembelajaran, melihat informasi baru, dan mengasimilasikan pemahaman peserta didik.

4. Menjadi kreatif tentang bagaimana proses belajar peserta didik dapat diperluas dengan menimba pengalaman dari dunia di luar tembok sekolah.

Asesmen autentik adalah komponen penting dari reformasi pendidikan sejak tahun 1990an. Wiggins (1993) menegaskan bahwa metode penilaian tradisional untuk mengukur prestasi, seperti tes pilihan ganda, benar/salah, menjodohkan, dan lain-lain telah gagal mengetahui kinerja peserta didik yang sesungguhnya. Tes semacam ini telah gagal memperoleh gambaran yang utuh mengenai sikap, keterampilan, dan pengetahuan peserta didik dikaitkan dengan kehidupan nyata mereka di luar sekolah atau masyarakat.

Asesmen hasil belajar yang tradisional bahkan cenderung mereduksi makna kurikulum, karena tidak menyentuh esensi nyata dari proses dan hasil belajar peserta didik. Ketika asesmen tradisional cenderung mereduksi makna kurikulum, tidak mampu menggambarkan kompetensi dasar, dan rendah daya prediksinya terhadap derajat sikap, keterampilan, dan kemampuan berpikir yang diartikulasikan dalam banyak mata pelajaran atau disiplin ilmu; ketika itu pula asesmen autentik memperoleh traksi yang cukup kuat. Memang, pendekatan apa pun yang dipakai dalam penilaian tetap tidak luput dari kelemahan dan kelebihan. Namun demikian, sudah saatnya guru profesional pada semua satuan pendidikan memandu gerakan memadukan potensi peserta didik, sekolah, dan lingkungannya melalui asesmen proses dan hasil belajar yang autentik.

Data asesmen autentik digunakan untuk berbagai tujuan seperti menentukan kelayakan akuntabilitas implementasi kurikulum dan pembelajaran di kelas tertentu. 
Data asesmen autentik dapat dianalisis dengan metode kualitatif, kuanitatif, maupun kuantitatif. Analisis kualitatif dari asesmen otentif berupa narasi atau deskripsi atas capaian hasil belajar peserta didik, misalnya, mengenai keunggulan dan kelemahan, motivasi, keberanian berpendapat, dan sebagainya. Analisis kuantitatif dari data asesmen autentik menerapkan rubrik skor atau daftar cek (checklist) untuk menilai tanggapan relatif peserta didik relatif terhadap kriteria dalam kisaran terbatas dari empat atau lebih tingkat kemahiran (misalnya: sangat mahir, mahir, sebagian mahir, dan tidak mahir). Rubrik penilaian dapat berupa analitik atau holistik.

Kebutuhan akan orientasi baru dalam pembelajaran ini terasa begitu kuat dan nyata dalam berbagai bidang studi, baik dalam bidang studi eksakta maupun ilmuilmu sosial. Para pendidik, praktisi pendidikan dan kita semua, mau tidak mau harus merespon perubahan yang terjadi dengan mengubah orientasi pembelajarannya. Untuk indikator keberhasilan dan Perubahan paradigma dalam proses pembelajaran dan asesmen seperti pada tabel 1 dan Tabel 2 berikut.

Tabel 1 Indikator Perubahan Orientasi Pembelajaran

\begin{tabular}{|c|c|c|}
\hline No & $\begin{array}{l}\text { Entitas } \\
\text { Pendidikan }\end{array}$ & Indikator Keberhasilan \\
\hline \multirow[t]{2}{*}{1} & Peserta Didik & Lebih produktif, kreatif, inovatif, afektif \\
\hline & & Lebih senang belajar \\
\hline \multirow[t]{4}{*}{2} & $\begin{array}{l}\text { Pendidik dan } \\
\text { Tenaga } \\
\text { Kependidikan }\end{array}$ & Lebih bergairah dalam melakukan proses pembelajaran \\
\hline & & Lebih mudah dalam memenuhi ketentuan 24 jam per minggu \\
\hline & \multirow{2}{*}{$\begin{array}{l}\text { Manajemen } \\
\text { Satuan } \\
\text { Pendidikan }\end{array}$} & $\begin{array}{l}\text { Lebih mengedepankan layanan pembelajaran termasuk } \\
\text { bimbingan dan penyuluhan }\end{array}$ \\
\hline & & $\begin{array}{l}\text { Terjadinya proses pembelajaran yang lebih variatif di } \\
\text { sekolah }\end{array}$ \\
\hline \multirow[t]{2}{*}{4} & $\begin{array}{l}\text { Negara dan } \\
\text { bangsa }\end{array}$ & Reputasi internasional pendidikannya menjadi lebih baik \\
\hline & & $\begin{array}{l}\text { Memiliki daya saing yang lebih tinggi, sehingga lebih menarik } \\
\text { bagi investor }\end{array}$ \\
\hline \multirow[t]{2}{*}{5} & $\begin{array}{l}\text { Masyarakat } \\
\text { Umum }\end{array}$ & Memperoleh lulusan sekolah yang lebih kompeten \\
\hline & & $\begin{array}{l}\text { Dapat berharap kebutuhan pendidikan akan dipenuhi oleh } \\
\text { sekolah (tidak perlu kursus tambahan) }\end{array}$ \\
\hline
\end{tabular}


Tabel 2. Perubahan paradigma untuk proses pembelajaran dan penilaian adalah

\begin{tabular}{|c|c|c|}
\hline No & Proses & Karakteristik Penguatan \\
\hline \multirow{4}{*}{1} & \multirow{4}{*}{ Pembelajaran } & $\begin{array}{l}\text { Menggunakan pendekatan saintifik melalui mengamati, } \\
\text { menanya, mencoba, menalar,.... }\end{array}$ \\
\hline & & $\begin{array}{l}\text { Menggunakan ilmu pengetahuan sebagai penggerak } \\
\text { pembelajaran untuk semua mata pelajaran }\end{array}$ \\
\hline & & $\begin{array}{l}\text { Menuntun siswa untuk mencari tahu, bukan diberi tahu } \\
\text { [discovery learning] }\end{array}$ \\
\hline & & $\begin{array}{l}\text { Menekankan kemampuan berbahasa sebagai alat } \\
\text { komunikasi, pembawa pengetahuan dan berfikir logis, } \\
\text { sistematis, dan kreatif }\end{array}$ \\
\hline \multirow{4}{*}{2} & \multirow{4}{*}{ Asesmen } & $\begin{array}{l}\text { Mengukur tingkat berfikir siswa mulai dari rendah sampai } \\
\text { tinggi }\end{array}$ \\
\hline & & $\begin{array}{l}\text { Menekankan pada pertanyaan yang mebutuhkan pemikiran } \\
\text { mendalam [bukan sekedar hafalan] }\end{array}$ \\
\hline & & Mengukur proses kerja siswa, bukan hanya hasil kerja siswa \\
\hline & & Menggunakan portofolio pembelajaran siswa \\
\hline
\end{tabular}

Tabel 3 berikut memperjelas perbedaan antara asesmen yang biasa digunakan dengan asesmen autentik:

Tabel 3. Perbandingan Asesmen Tradisional dan Autentik

\begin{tabular}{|l|l|}
\hline \multicolumn{1}{|c|}{ Asesmen Tradisional } & \multicolumn{1}{c|}{ Asesmen Autentik } \\
\hline $\begin{array}{l}\text { Memilih/Merespon: Siswa } \\
\text { memililh jawaban, menentukan } \\
\text { pilihan, dan menjawab dengan } \\
\text { uraian. }\end{array}$ & $\begin{array}{l}\text { Melaksanakan kegiatan:Siswa } \\
\text { melakukan aktivitas yang } \\
\text { sesungguhnya sehingga } \\
\text { memperoleh pengalaman belajar. }\end{array}$ \\
\hline $\begin{array}{l}\text { Dikondisikan: Akavitas siswa } \\
\text { dikondisikan sesuai dengan } \\
\text { keinginan penguji, seperti memilih } \\
\text { jawaban yang dikodisikan guru. }\end{array}$ & $\begin{array}{l}\text { Kenyataan Hidup: Guru } \\
\text { menilai kenyataan yang } \\
\text { kesungguhnya siswa lakukan pada } \\
\text { kehidupan nyata dalam waktu } \\
\text { pendek. }\end{array}$ \\
\hline
\end{tabular}




\begin{tabular}{|l|l|}
\hline $\begin{array}{l}\text { Mengingat/ Menyatakan:Siswa } \\
\text { mengingat atau menyatakan } \\
\text { informasi yang mereka kuasai. }\end{array}$ & $\begin{array}{l}\text { Konstruksi/Aplikasi: Penilaian } \\
\text { Autentik memperhatikan siswa } \\
\text { menganalisis atau } \\
\text { mengaplikasikan ilmu dalam } \\
\text { proses berkreasi, berinovasi atau } \\
\text { mencipta.. }\end{array}$ \\
\hline $\begin{array}{l}\text { Struktur Dirancang Guru: Siswa } \\
\text { perlu berhati-hati untuk } \\
\text { mengembangkan struktur yang } \\
\text { guru harapkan, memenuhi target } \\
\text { seperti yang guru inginkan. }\end{array}$ & $\begin{array}{l}\text { Siswa: Penilaian autentik memberi } \\
\text { ruang kepada } \\
\text { siswa mengembangkan } \\
\text { konstruksi sesuai dengan } \\
\text { keinginannya }\end{array}$ \\
\hline $\begin{array}{l}\text { Bukti Tidak Langsung: Dalam } \\
\text { penilaian tradisional melalui tes } \\
\text { pilihan ganda, misalnya, } \\
\text { memperoleh bukti kompetensi } \\
\text { siswa tidak langsung }\end{array}$ & $\begin{array}{l}\text { Bukti Langsung: Dalam penilaian } \\
\text { autentik guru memperoleh bukti } \\
\text { langsung tentang perkembangan } \\
\text { kompetensi yang ditunjukkan siswa } \\
\text { secara langsung }\end{array}$ \\
\hline
\end{tabular}

Berdasarkan indikator keberhasilan dan Perubahan paradigma dalam proses pembelajaran dan asesmen seperti terungkap pada tabel 1, 2 dan 3 di atas maka orientasi pembelajaran disarankan sebagai berikut ini:

\section{Dari berpusat pada guru menuju berpusat pada siswa}

Jika dahulu biasanya yang terjadi adalah guru berbicara dan siswa mendengar, menyimak, dan menulis - maka saat ini guru harus lebih banyak mendengarkan siswanya saling berinteraksi, berargumen, berdebat, dan berkolaborasi. Fungsi guru dari pengajar berubah dengan sendirinya menjadi fasilitator bagi siswasiswanya.

\section{Dari satu arah menuju interaktif}

Jika dahulu mekanisme pembelajaran yang terjadi adalah satu arah dari guru ke siswa, maka saat ini harus terdapat interaksi yang cukup antara guru dan siswa dalam berbagai bentuk komunikasinya. Guru berusaha membuat kelas semenarik mungkin melalui berbagai pendekatan interaksi yang dipersiapkan dan dikelola.

\section{Dari isolasi menuju lingkungan jejaring}

Jika dahulu siswa hanya dapat bertanya pada guru dan berguru pada buku yang ada di dalam kelas semata, maka sekarang ini yang bersangkutan dapat menimba ilmu dari siapa saja dan dari mana saja yang dapat dihubungi serta diperoleh via internet. 


\section{Dari pasif menuju aktif-menyelidiki}

Jika dahulu siswa diminta untuk pasif saja mendengarkan dan menyimak baikbaik apa yang disampaikan gurunya agar mengerti, maka sekarang disarankan agar siswa harus lebih aktif dengan cara memberikan berbagai pertanyaan yang ingin diketahui jawabannya.

\section{Dari maya/abstrak menuju konteks dunia nyata}

Jika dahulu contoh-contoh yang diberikan guru kepada siswanya kebanyakan bersifat artifisial, maka saat ini sang guru harus dapat memberikan contoh-contoh yang sesuai dengan konteks kehidupan sehari-hari dan relevan dengan bahan yang diajarkan.

6. Dari pribadi menuju pembelajaran berbasis tim Jika dahulu proses pembelajaran lebih bersifat personal atau berbasiskan masing-masing individu, maka yang harus dikembangkan saat ini adalah model pembelajaran yang mengedepankan kerjasama antar individu.

7. Dari luas menuju perilaku khas memberdayakan kaidah keterikatan Jika dahulu ilmu atau materi yang diajarkan lebih bersifat umum (semua materi yang dianggap perlu diberikan), maka saat ini harus dipilih benar-benar ilmu atau materi

yang benar-benar relevan untuk ditekuni dan diperdalam secara sungguhsungguh (hanya materi yang relevan bagi kehidupan sang siswa yang diberikan).

8. Dari stimulasi rasa tunggal menuju stimulasi ke segala penjuru Jika dahulu siswa hanya menggunakan sebagian panca inderanya dalam menangkap materi yang diajarkan guru (mata dan telinga), maka saat ini seluruh panca indera dan komponen jasmani-rohani harus terlibat aktif dalam proses pembelajaran (kognitif, afektif, dan psikomotorik).

9. Dari alat tunggal menuju alat multimedia

Jika dahulu ilmu guru hanya mengandalkan papan tulis untuk mengajar, maka saat ini diharapkan guru dapat menggunakan beranekaragam peralatan dan teknologi pendidikan yang tersedia - baik yang bersifat konvensional maupun moderen.

10. Dari hubungan satu arah bergeser menuju kooperatif Jika dahulu siswa harus selalu setuju dengan pendapat guru dan tidak boleh sama sekali menentangnya, maka saat ini harus ada dialog antar guru dan siswa untuk mencapai kesepakatan bersama.

\section{Dari produksi massa menuju kebutuhan pelanggan}

Jika dahulu seluruh siswa tanpa kecuali memperoleh bahan atau konten materi yang sama, maka sekarang ini setiap siswa berhak untuk mendapatkan konten sesuai dengan ketertarikan atau keunikan potensi yang dimilikinya 


\section{Dari usaha sadar tunggal menuju jamak}

Jika dahulu siswa harus secara seragam mengikuti sebuah cara dalam berproses maka yang harus ditonjolkan saat ini justru adanya keberagaman inisiatif yang timbul dari masing-masing individu

13. Dari satu ilmu pengetahuan bergeser menuju pengetahuan disiplin jamak Jika dahulu siswa hanya mempelajari sebuah materi atau fenomena dari satu sisi pandang ilmu, maka saat ini konteks pemahaman akan jauh lebih baik dimengerti melalui pendekatan pengetahuan multi disiplin.

\section{Dari kontrol terpusat menuju otonomi dan kepercayaan} Jika dahulu seluruh kontrol dan kendali kelas ada pada sang guru, maka sekarang ini siswa diberi kepercayaan untuk bertanggung jawab atas pekerjaan dan aktivitasnyamasing-masing.

\section{Dari pemikiran faktual menuju kritis} Jika dahulu hal-hal yang dibahas di dalam kelas lebih bersifat faktual, maka sekarang ini harus dikembangkan pembahasan terhadap berbagai hal yang membutuhkan pemikiran kreatif dan kritis untuk menyelesaikannya.

\section{Dari penyampaian pengetahuan menuju pertukaran pengetahuan} Jika dahulu yang terjadi di dalam kelas adalah "pemindahan" ilmu dari guru ke siswa, maka dalam abad moderen ini yang terjadi di kelas adalah pertukaran pengetahuan antara guru dan siswa maupun antara siswa dengan sesamanya

\section{Langkah-langkah Menciptakan Penilaian Otentik}

Siswa diminta menampilkan sejumlah tugas dalam dunia sesungguhnya yang memperlihatkan aplikasi keterampilan dan pengetahuan yang esensial dengan langkahlangkah sebagai berikut:

\section{Langkah 1 Mengidentifikasi capaian kemampuan akhir peserta didik}

Seperti merumuskan pernyataan untuk tujuan umum (goal) dari pembelajaran, scapaian kemampuan akhir merupakan pernyataan yang harus diketahui dan dapat dilakukan siswa, tetapi ruang lingkupnya lebih sempit dan lebih mudah dicapai daripada tujuan umum. Ditulis dalam pernyataan singkat yang harus diketahui atau mampu dilakukan siswa pada poin tertentu. Agar operasional, rumusan standar hendaknya dapat diobservasi dan dapat diukur.

\section{Langkah 2 Memilih suatu tugas otentik}

Dalam memilih tugas otentik, pertama-tama kita perlu mengkaji standar yang kita buat, dan mengkaji kenyataan (dunia) sesungguhnya. Misalnya daripada meminta siswa menyelesaikan soal pecahan, lebih baik kita siapkan tugas memecahkan masalah yang 
terjadi dikehidupan sehari-hari.

\section{Langkah 3 Mengidentifikasi Kriteria untuk tugas (tasks)}

Kriteria tidak lain adalah indikator-indikator dari kinerja yang baik pada

sebuah tugas. Apabila terdapat sejumlah indikator, sebaiknya diperhatikan

apakah indikator-indikator tersebut sekuensial (memerlukan urutan) atau tidak.

\section{a. Contoh-contoh kriteria}

Contoh sejumlah indikator dalam urutan (menggunakan thermometer):

1. Mengeluarkan thermometer dari tempat dengan memegang bagian ujung termometer yang tak berisi air raksa

2. Menurunkan posisi air raksa dalam pipa kapiler termometer serendah-rendahnya

3. Memasang termometer pada psien ( dimulut atau diketiak ) sehingga bagian yang berisi air raksa terkontak dengan tubuh pasien

4. Menunggu beberapa menit ( membiarkan termometer menempel ditubuh pasien selama beberapa menit ).

5. Mengambil termometer dari tubuh pasien, dengan memegang bagian ujung termometer yang tidak berisi air raksa.

6. Membaca tinggi air raksa dalam pipa kapiler dengan posisi mata tegak lurus

b. Karakteristik suatu kriteria yang baik

Kriteria yang baik antara lain adalah sebagai berikut.

1. dinyatakan dengan jelas, singkat;

2. pernyataan tingkah laku, dapat diamati;

3. ditulis dalam bahasa yang dipahami siswa.

\section{c. Jumlah Kriteria untuk sebuah task}

Hal-hal yang perlu diperhatikan adalah sebagai berikut.

1. batasi jumlah kriteria, hanya pada unsur-unsur yang esensial dari suatu tugas (antara 3-4, di bawah 10);

2. tidak perlu mengukur setiap detil tugas;

3. Kriteria yang lebih sedikit untuk tugas-tugas yang lebih kecil atau sederhana.

Contoh tes singkat atau kuis diberikan berikut ini sebagai latihan 
Tugas 1: Tuliskan tiga kriteria bagi seorang petugas laboratorium yang baik

Tugas 2: Tuliskan empat kriteria berlakunya hukum Newton

Tugas 3: Tuliskan tiga kriteria presentasi lisan yang baik.

\section{Langkah 4 Menciptakan standar kriteria atau rubrik (rubrics)}

\section{a. Menyiapkan suatu rubrik analitis}

Dalam rubrik tidak selalu diperlukan deskriptor. Deskriptor merupakan karakteristik perilaku yang terkait dengan level-level tertentu, seperti observasi mendalam, prediksinya beralasan, kesimpulannya berdasarkan hasil observasi.

\section{b. Menyiapkan suatu rubrik yang holistic}

Dalam rubrik holistic, dilakukan pertimbangan seberapa baik seseorang telah menampilkan tugasnya dengan mempertimbangkan kriteria secara keseluruhan. Sebagai contoh, dalam praktikum dapat disiapkan rubrik keseluruhan sebagai berikut.

\section{c. Mencek rubrik yang telah dibuat}

Untuk keperluan pengecekan rubrik yang telah dibuat sebaiknya kita meminta kepada rekan kerja sesama guru untuk mereviunya, atau meminta siswa mengenai kejelasannya. Masukan dari mereka dapat digunakan untuk memperbaiki standar yang telah kita siapkan. Ada baiknya kita juga memeriksa atau mencek apakah rubrik tersebut dapat dikelola dengan mudah. Bayangkan penampilan atau kinerja siswa ketika sedang melakukannya.

\section{Contoh Iplementasi Penilaian Otentik untuk Pembelajaran Fisika}


Contoh ketrampilam membuat grafik.

Tujuan pembuatan grafik untuk menunjukkan perbandingan, informasi yang kualitatif dengan cepat dan sederhana. Data-data dalam bentuk uraian deskriptif yang ruwet dan juga kompleks bisa disederhanakan dengan menggunakan grafik. Jadi, jika sebuah grafik sulit dibaca atau dipahami berarti akan kehilangan manfaatnya yang berharga.

Fungsi grafik yaitu untuk menggambarkan data-data dalam bentuk angka (data kuantitatif) secara teliti dan menerangkan perkembangan serta perbandingan suatu obyek ataupun peristiwa yang saling berhubungan secara singkat dan jelas. Jadi dapat disimpulkan fungsi grafik:

1. Menggambarkan data kuantitatif dengan teliti.

2. Menerangkan perkembangan, perbandingan suatu obyek ataupun peristiwa yang saling berhubungan secara singkat dan jelas. Grafik disusun berdasarkan prinsipprinsip matematika dengan menggunakan data-data yang komparatif.

untuk jelasnya pertama di buat matrik keterangan setiap langkah

\begin{tabular}{|c|c|c|}
\hline Langkah & Keterangan & Contoh \\
\hline $\begin{array}{l}\text { Langkah } 1 \\
\text { Menentukan } \\
\text { capaian } \\
\text { kemampuan akhir }\end{array}$ & $\begin{array}{l}\text { Ditulis dalam pernyataan singkat } \\
\text { yang harus diketahui atau mampu } \\
\text { dilakukan siswa pada poin } \\
\text { tertentu. } \\
\text { Agar operasional, rumusan } \\
\text { standar hendaknya dapat } \\
\text { diobservasi dan dapat diukur }\end{array}$ & $\begin{array}{l}\text { Siswa mampu membuat grafik } \\
\text { dengan benar }\end{array}$ \\
\hline $\begin{array}{l}\text { Langkah } 2 \\
\text { Memilih suatu } \\
\text { tugas otentik }\end{array}$ & $\begin{array}{l}\text { Mengkaji standar yang kita buat, } \\
\text { dan mengkaji kenyataan (dunia) } \\
\text { sesungguhnya. } \\
\text { Menyiapkan tugas memecahkan } \\
\text { masalah yang terjadi dikehidupan } \\
\text { sehari-hari. }\end{array}$ & $\begin{array}{l}\text { Menentukan nilai komponen } \\
\text { tahanan melalui grafik }\end{array}$ \\
\hline $\begin{array}{l}\text { Langkah } 3 \\
\text { Mengidentifikasi } \\
\text { Kriteria untuk tugas } \\
\text { (tasks) }\end{array}$ & 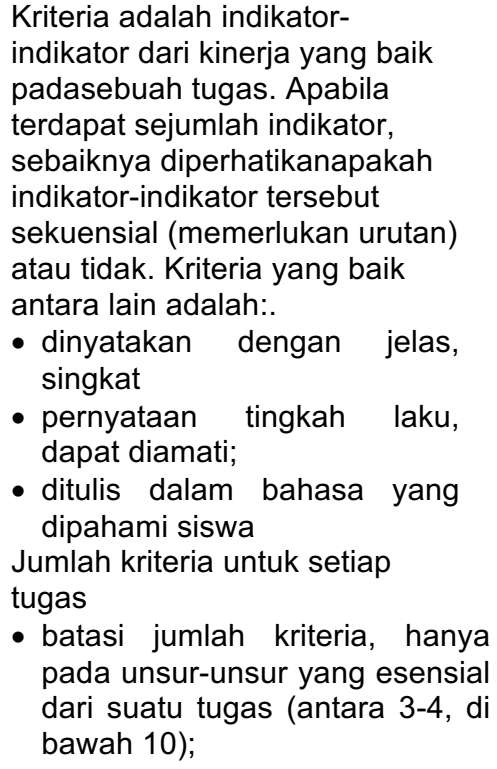 & $\begin{array}{l}\text { 1. Jenis grafik yang digunakan } \\
\text { sesuai. } \\
\text { 2. Digunakan titik awal dan interval } \\
\text { yang sesuai untuk tiap sumbu } \\
\text { grafik. } \\
\text { 3. Digunakan skala yang sesuai } \\
\text { pada tiap sumbu bergantung } \\
\text { pada rentang data untuk sumbu } \\
\text { tersebut. } \\
\text { 4. Ada judul utama untuk grafik } \\
\text { tersebut, yang dengan jelas } \\
\text { menyatakan hubungan antara } \\
\text { sumbu-sumbu grafik tersebut. } \\
\text { 5. Sumbu-sumbu grafik dilabel } \\
\text { dengan jelas. } \\
\text { 6. Variabel bebas diletakkan pada } \\
\text { sumbu } X \text { dan variabel tak-bebas } \\
\text { pada sumbu } Y \text {. }\end{array}$ \\
\hline
\end{tabular}




\begin{tabular}{|c|c|c|}
\hline & $\begin{array}{l}\text { - tidak perlu mengukur setiap detil } \\
\text { tugas; } \\
\text { - Kriteria yang lebih sedikit untuk } \\
\text { tugas-tugas yang lebih kecil } \\
\text { atau sederhana }\end{array}$ & $\begin{array}{l}\text { 7. Data tersebut diplot secara } \\
\text { cermat. } \\
\text { 8. Warna, textur, label, atau fitur } \\
\text { lain digunakan untuk membuat } \\
\text { grafik tersebut lebih mudah } \\
\text { dibaca. } \\
\text { 9. Grafik tersebut rapi dan } \\
\text { disajikan dengan baik. }\end{array}$ \\
\hline $\begin{array}{l}\text { Langkah } 4 \\
\text { Menciptakan } \\
\text { standar kriteria } \\
\text { atau rubrik } \\
\text { (rubrics) }\end{array}$ & $\begin{array}{l}\text { Menyiapkan suatu rubrik analitis } \\
\text { dan atau rubrik yang holistic } \\
\text { Mencek rubrik yang telah dibuat }\end{array}$ & $\begin{array}{l}\text { Asesmen diri peserta didik } \\
\text { Seberapa baik seseorang telah } \\
\text { menampilkan tugasnya dengan } \\
\text { mempertimbangkan kriteria } \\
\text { secara keseluruhan Rubrik yang } \\
\text { telah dibuat sebaiknya kita } \\
\text { meminta kepada rekan kerja } \\
\text { sesama guru untuk mereviunya, } \\
\text { atau meminta siswa mengenai } \\
\text { kejelasannya }\end{array}$ \\
\hline
\end{tabular}

Nama (Kelompok):

Kelas:

Tgl:

\section{Alat dan Bahan: tidak memerlukan alat}

\section{TUGAS: Membuat Graf}

Reza ingin menukar komponen resistor boster TV nya yang patah dan nilai tahanan tersebut tidak bisa dibaca lansung. Alat ukur Reza hanya bisa mengukur tegangan dan arus. Reza mempunyai 6 batray, dengan memvariasikan jumlah batray Reza membuat rangkaian dan mengukur arusnya

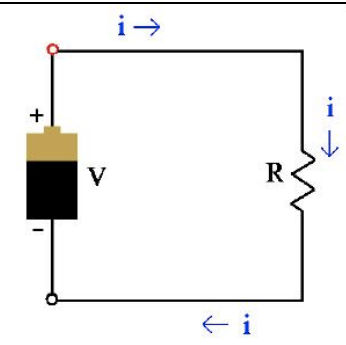

Data Hasil pengukuran Reza untuk tegangan (v), arus (i) dari rangkaian seperti pada gambar disajikan dalam bentuk tabel

\begin{tabular}{|l|l|l|}
\hline $\begin{array}{l}\text { Jml } \\
\text { Batray }\end{array}$ & $\begin{array}{l}\text { Voltas } \\
\text { e } \\
(\text { Volt })\end{array}$ & $\begin{array}{l}\text { Arus } \\
(\mathrm{mA})\end{array}$ \\
\hline 1 & 1.5 & 30 \\
\hline 2 & 3 & 60 \\
\hline 3 & 4.5 & 90 \\
\hline 4 & 6 & 120 \\
\hline 5 & 7.5 & 150 \\
\hline 6 & 9 & 180 \\
\hline
\end{tabular}

Prosedur

1. Berikan tabel data di atas kepada peserta didik.

2. Tugaskan peserta didik untuk menyajikan data dalam tabel tersebut dalam bentuk grafik.

Tentukan tahanan $(\mathrm{R})$ dari garafik yang di peroleh 


\section{DAFTAR BACAAN}

Undang-Undang (UU) nomor 20 tahun 2003 tentang Sistem Pendidikan Nasional, UU nomor 12 tahun 2012 tetang pendidikan

Peraturan Pemerintah Nomor 8 tahun 2012 tentang KKNI (Kerangka kualifikasi nasional indonesia).

O'Malley, J.M., Pierce, L.V. 1996. Authentic Assessment for English Language Learners Practical Approaches for Teachers. Printed in the United States of America: Addison-Wesley Publishing Company, Inc.

Assessment in The Science Classroom. New York: Glencoe/McGraw-Hill. ISBN 0-07-825453-1.

Gronlund, N.E. (1998). Assessment of Student Achievement. 6th ed. Boston:

Allyn and Bacon.

Depdiknas. (2014). Peraturan Pemerintah Republik Indonesia Nomor 49 tahun 2014 tentang StandarNasiona Pendidikan Tinggi Jakarta: Depdiknas

Depdiknas.(2010). Peraturan Pemerintah Nomor 66 Tahun 2010 tentang Perubahan Atas Peraturan Pemerintah Nomor 17 Tahun 2010 tentang Pengelolaan dan Penyelenggaraan Pendidikan. Jakarta: Depdiknas.

Festiyed. (2005). Pengembangan Kurikulum Fisika FMIPA UNP Beorientasi Kecakapan Hidup (Life Skill), Makalah Seminar Kurikulum, Pasca Sarjana UNP Padang

Popham, W. J. (1995). Classroom Assessment: What Teachers Need to Know. Boston: Allyn and Bacon.

Tilaar, H.A.R. (Ed.). 2004. Paradigma Baru Pendidikan Nasional. Jakarta: Rineka Cipta

Endrotomo(2010) . Presentasi seminar dan workshop di UNP 2010

M.Nur (2009). Presentasi seminar dan workshop di UNP 2009

Nuryani Y. Rustaman. Artikel diklat 